\title{
Development and root morphology of passion fruit in different substrates
}

\section{Desarrollo y morfología de la raíz del maracuyá en diferentes substratos}

KARMINNE DIAS DO VALLE', 3

LAÍSSE DANIELLE PEREIRA ${ }^{1}$

MOAB ACÁCIO BARBOSA'

VANESSA BRENDA SOUZA CHAVES' ${ }^{1}$

PEDRO HENRIQUE MAGALHÃES DE SOUZA ${ }^{1}$

EDÉSIO FIALHO DOS REIS ${ }^{1}$

ALEJANDRO HURTADO-SALAZAR ${ }^{2}$

DANIELLE FABÍOLA PEREIRA DA SILVA'

Passion fruit nursery.

Photo: K.D.d. Valle

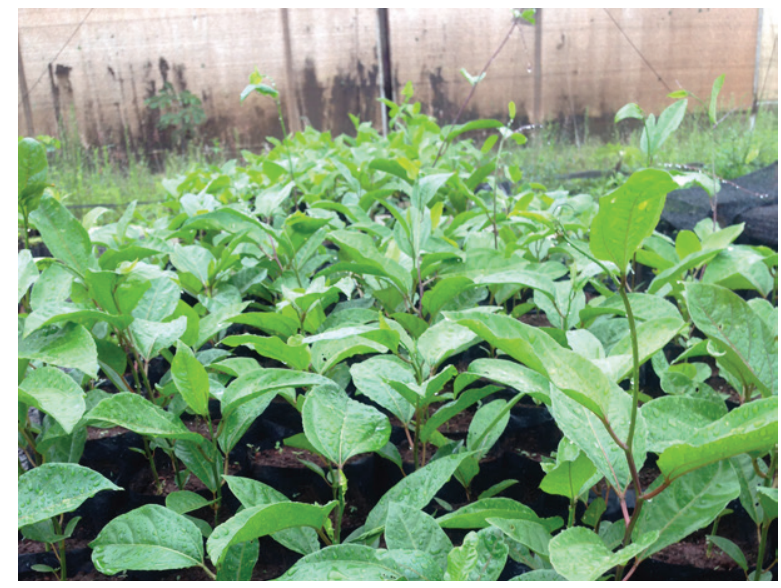

\section{ABSTRACT}

Among the factors that contribute to better initial development of plants, it is the substrate used. Therefore, this study aimed to evaluate the effect of substrate in initial formation and morphology of the roots of two species of passion fruits. The analyses were done in the nursery of the Federal University of Goiás (UFG), Regional Jataí, Brazil, with a light interception of $60 \%$. The material used were seeds of yellow passion fruit (Passiflora edulis f. flavicarpa) and the cultivar FB 200 (Flora Brasil), harvested in the UFG experimental field. They were sown in three types of substrates: Soil I (mixture of soil, chicken manure and sand in a ratio of 2:1:1 by volume), soil II (steep bank), and Bioplant ${ }^{\circledR}$, using for plants perforated bags with a capacity of 1.5 L. The experimental design was a completely randomized design with six treatments, eight replications and four plants per plot. After 30 days of sowing, fresh matter of root, root dry matter and morphology were evaluated. The substrate affected the initial development of yellow passion fruit, obtaining the best results with Bioplant ${ }^{\circledR}$, showing as promising for the development of all the evaluated characteristics.

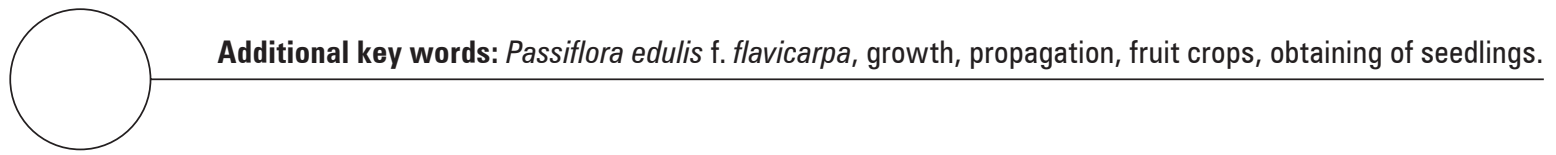

\footnotetext{
Universidade Federal de Goiás, Regional Jataí, Jataí-GO (Brazil). ORCID Valle, K.D.d.: 0000-0002-4020-4169; ORCID Pereira, L.D.: 0000-0002-2977-3870; ORCID Barbosa, M.A.: 0000-0001-6937-5642; ORCID Chaves, V.B.S.: 0000-0001-7159-334X; ORCID Souza, P.H.M.d.: 0000-0002-4824-0738; ORCID Reis, E.F.d.: 0000-0002-8000-3513; ORCID Silva, D.F.P.d.: 0000-0001-7366-5650

2 Department of Agricultural Production, Universidad de Caldas, Manizales (Colombia). ORCID Hurtado-Salazar, A.: 0000-0002-1251-125X

3 Corresponding author. karminnevalle@gmail.com
} 


\section{RESUMEN}

Entre los factores que contribuyen para un correcto desarrollo inicial de las plantas, está el sustrato utilizado, por tanto, el objetivo del presente estudio fue evaluar el efecto del sustrato en la formación inicial y morfología de las raíces de dos especies de maracuyá. El experimento fue realizado en vivero con polisombra de interceptación luminosa (60\%), en la Universidad Federal de Goiás (UFG), Regional Jataí, Brasil. Los materiales utilizados fueron maracuyá (Passiflora edulis f. flavicarpa) y el cultivar FB 200 (Flora Brasil). Se utilizaron semillas de frutos recolectados del huerto experimental de la UFG. Se sembraron en tres tipos de sustratos: Suelo I (mezcla de 2 partes de suelo +1 parte de gallinaza +1 parte de arena), Suelo II (suelo de barranco) y Bioplant ${ }^{\oplus}$; se utilizó bolsas perforadas para plántulas con capacidad de 1,5 L. El diseño experimental utilizado fue completamente aleatorio con seis tratamientos, ocho repeticiones y cuatro plántulas por parcela. Después de 30 días de siembra, se evaluó: peso fresco de la raíz, peso seco de raíz y morfología de la raíz. El sustrato tuvo efecto en el desarrollo inicial de las plantas de maracuyá, donde se obtuvo los mejores resultados con Bioplant ${ }^{\oplus}$. Este sustrato sobresalió en todas las características evaluadas mostrando su potencialidad en la propagación de esta especie.

Palabras clave adicionales: Passiflora edulis f. flavicarpa, crecimiento, propagación, frutales, obtención de plántulas.

Received for publication: 26-02-2018 Accepted for publicacation: 30-05-2018

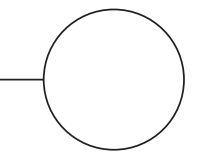

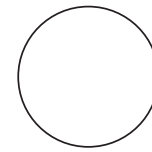

In recent years, the demand for food is increasing and this situation will continue as a progressive function of population growth. Therefore, the need to produce efficiently, with quality and low costs are growing. The basis for the production lies in obtaining of quality seedlings. With this, the high productivity of quality fruits is directly linked to the use of good techniques for raising of seedlings, because they need to be vigorous for a better capacity of adaptation and resistance to climatic conditions. Zaccheo et al. (2013) found that $60 \%$ of the success of a plant culture depends on quality seedlings.

The cultivation of passion fruits became increasing both by favorable climatic conditions, as well as the acceptability for the industry in the form of pulp (Meletti, 2011). By leveraging the diversification, the culture of passion fruit has been occupying a prominent place for small farms, as an alternative agricultural fast economic return.

The propagation of this fruit is usually done through seeds (Meletti, 2011) however this can also be performed by means of cuttings and grafting (Leonel and Pedroso, 2005). Even when propagated by sexual, presents characteristics of early fruiting, which reason the vegetative propagation is not strictly necessary to reduce the period of juvenility of the plant.
Roncatto et al. (2008) pointed out the importance of conducting seedlings into individual containers, because such practice provides greater precocity and reduction of possible contamination by pathogens. In addition to the types of container, several factors also influence the final quality of changes, such as quality and seed health, crop management such as irrigation and fertilization, and technologies for example types of protected environments (Lima et al., 2016).

According to Lima et al. (2016) different studies with pure commercial substrate Plantmax ${ }^{\circledR}$ and/or in mixture with manure, soil and vermiculite have provided high quality passion fruit seedlings. Negreiros et al. (2004) observed that the use of Plantmax ${ }^{\circledR}$ and the substrate composed of sand, vermiculite, manure (1:1:1), supplemented with $10 \mathrm{~kg} \mathrm{~m}^{-3}$ of single superphosphate, $6 \mathrm{~kg} \mathrm{~m}^{-3}$ of potassium chloride, $2 \mathrm{~kg} \mathrm{~m}^{-3}$ of urea and $8 \mathrm{~kg} \mathrm{~m}^{-3}$ of limestone promoted a higher percentage of germination and adequate development of passion fruit seedlings.

The use of suitable substrates and the addition of formulations in the current system of production is considered beneficial. For that to happen and bring reduction in the final costs is necessary to mix different components to obtain a suitable substrate (Almeida et al., 2014). 
In view of the foregoing and showing to find the best substrate for seedling production, the present aimed to evaluate the development and the morphology of the root system of passion fruit plants, using three types of substrate.

\section{MATERIAL AND METHODS}

The experiment was carried out in the nursery (with light interception of $60 \%$ ) of the Federal University of Goias, Regional Jataí, Jatai-GO, Brazil. This experimental nursery is located at $17^{\circ} 55^{\prime} \mathrm{S}$ and $51^{\circ} 43^{\prime} \mathrm{W}$. According to the classification of Köppen, the climate of the region is the Aw type, megatermic, with a defined dry season from May to September and the rainy season from October to April. The average temperature is $23.3^{\circ} \mathrm{C}$ and the average annual rainfall 1,541 $\mathrm{mm}$ (Cardoso et al., 2014).

Seeds of yellow passion fruit (P. edulis f. flavicarpa) and FB 200 Flora (Brazil), removed from fruits harvested from experimental arrays of orchards, were selected from fruits of healthy plants, free of pests and diseases. Fruits were harvested manually with pruning shears, using as a criterion of harvest stage the yellow color of the epidermis.

Once harvested, the fruits were sectioned and the mucilage with the seeds were removed by means of water + quicklime. Subsequently, the seeds were placed in polyethylene sieve and washed in running water.

After taking off from these seeds were sown using three seeds per bag at $1.0 \mathrm{~cm}$ depths in three types of substrates (Soil I; Soil II and Bioplant ${ }^{\circledR}$ ), using perforated bags for plants with a capacity of $1.5 \mathrm{~L}$. After germination, which occurred 15 days after sowing (das), the seedlings were thinned out leaving only the most vigorous one.

According to the manufacturer, the Bioplant ${ }^{\circledR}$ is composed of coconut fiber, bark of pinus, dung, sawdust, vermiculite, carbonized rice, peat of sphagnum, gypsum, calcium carbonate, magnesium, magnesium thermophosphate (yoorin) and additives (fertilizer), made by Bioplant Agrícola Ltda., Nova Ponte-MG, Brazil. The Soil I is mixed by 2 parts of soil +1 part of chicken manure +1 part of sand (2:1:1, by volume), whose mixture had a $\mathrm{pH}\left(\mathrm{CaCl}_{2}\right)$ of 5.3 ; $\mathrm{P}$ of $21.9 \mathrm{mg}$ $\mathrm{dm}^{-3}$; K of $1.10 \mathrm{cmolc} \mathrm{dm}^{-3}$ and $\mathrm{Mg}$ of $0.57 \mathrm{cmolc} \mathrm{dm}^{-}$

${ }^{3}$, whithout any correction in the mixture itself. The
Soil II was characterized with a $\mathrm{pH}\left(\mathrm{CaCl}_{2}\right)$ of $5.9, \mathrm{P}$ of $3.0 \mathrm{mg} \mathrm{dm}^{-3}$; K of $0.02 \mathrm{cmolc} \mathrm{dm}^{-3}$ and $\mathrm{Mg}$ of 0.14 cmolc $\mathrm{dm}^{-3}$, which was corrected in accordance with the needs of the culture.

The following parameters were evaluated at 35,40 , 45, 50 and 55 das: fresh root matter (FRM), root dry matter (RDM) and root morphology.

At 30 das, contents of FRM and RDM were evaluated of normal seedlings, where the parts (roots and aerial parts) were separated. The roots were washed and weighed individually with a precision electronic scale of $0.1 \mathrm{~g}$. Afterwards, they were subjected to drying in an oven at $70^{\circ} \mathrm{C}$ for $24 \mathrm{~h}$, to obtain the dry matter (g), according to the methodology described by Nakagawa (1999).

The experimental design was a completely randomized design with six treatments, eight replications and four plants per plot. The averages of the analyzed variables were compared by the Tukey test at $5 \%$ probability. The calculations concerning the statistical analyzes were performed using the statistical software SAS (Statistical Analysis System, 2002). For the quantitative data a regression analysis (Gomes, 2000) was applied. In order to describe better the root development, a morphological analysis was made, by means of image comparison.

\section{RESULTS AND DISCUSSION}

The passion fruit seedlings showed variations in growth, influenced by the substrate. At 30 das, the cultivar FB 200 presented a higher initial performance in Soil II, with a RFM of $0.1833 \mathrm{~g}$, and the exponential equation that fit best. For Soil I and Bioplant ${ }^{\circledR}$ the measured results of RFM and RDM of FB200 seedlings adjusted to the quadratic model, in response to the variation of time (Fig. 1).

At 35, 40, 45, 50 and 55 das, a higher development of plants, cultivated in Bioplant ${ }^{\circledR}$ substrate was observed (Fig. 1). These results are due to the fact that the commercial substrate probably gathers physical, chemical and biological characteristics which are appropriate and well balanced, that influenced positively the weight gain and the morphology of plants, highlighting the importance of the substrate on the quality in the seedlings production (Fig. 2). 
Differences were observed in the morphology and the formation of the root system, where the roots, developed in the Bioplant ${ }^{\circledR}$ substrate showed a higher branching and also were larger (Fig. 2). Roots in Soil

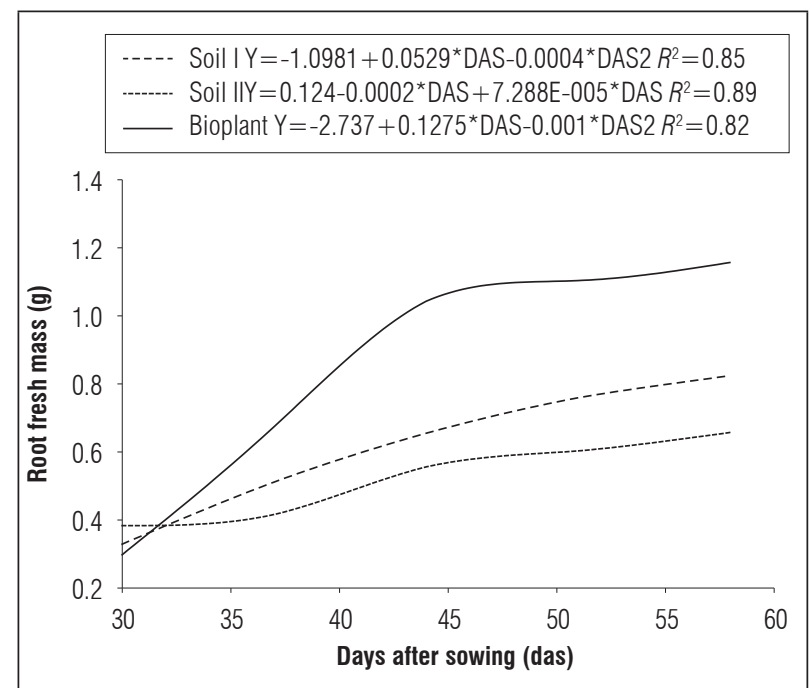

Figure 1. Adjusted data for root fresh mass of 'FB 200' passion fruit plants in three substrates after sowing.
I were less widespread, but with greater thickness, compared to the other treatments. In Soil II, root ramifications were longer and showed a greater thickness than in Bioplant ${ }^{\circledR}$, but were lower than on the Soil I.

Lenhard et al. (2013), in studies conducted with the growth of Pau Ferro (Libidibia ferrea) seedlings, stated that the reduction of the time in the nursery facilitates the logistics and minimizes production costs, which matches with the experience of Silva et al. (2016), in which the use of a commercial substrate in the production of passion fruit seedlings promoted a greater growth of seedlings, favoring not only in reducing the time of plant development, but also in the logistics and the final costs.

FB200 variety, at 60 das, showed a RFM on the three substrates - Soil I, Soil II and Bioplant ${ }^{\circledR}$ - of 0.6259, 0.3741 and 0.9528 g, respectively (Fig. 1). Again, in the Bioplant ${ }^{\circledR}$ substrate a greater root development, as well as a greater accumulation of fresh matter, was observed. Similar results were found by Ferreira et al. (2009) who studied the influence of the substrate on the growth of cupuaçu (Theobroma grandiflorum)

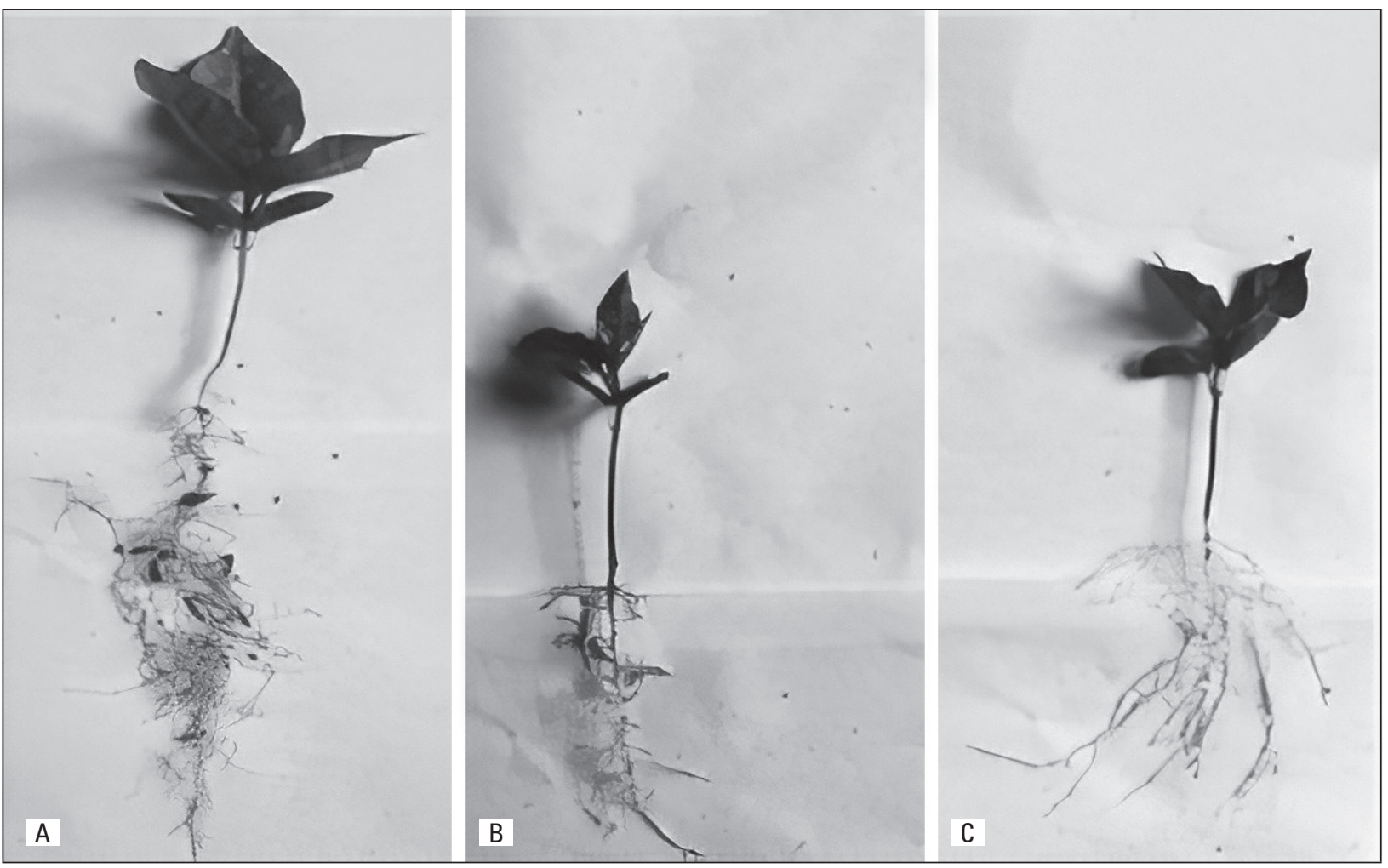

Figure 2. The root morphology of 'FB 200' passion fruit plants, $30 \mathrm{~d}$ after sowing in three types of substrate. A. Soil I; B. Soil II; C. Bioplant ${ }^{\circledR}$. 
seedlings, using the substrate Bioplant ${ }^{\circledR}$, where a minimal production of aerial part, but a maximum production of roots was observed.

For the variable root dry mass, the substrate Bioplant ${ }^{\circledast}$ differ from other substrates, where a quadratic behavior in response to the size of the container used was observed, and where the roots at 50 das restricted their growth (Fig. 3). The values obtained at $35,40,45,50$ and 55 das were $0.0156,0.0419,0.1019$, $0.0707,0.1355 \mathrm{~g}$ for 'FB 200', respectively.

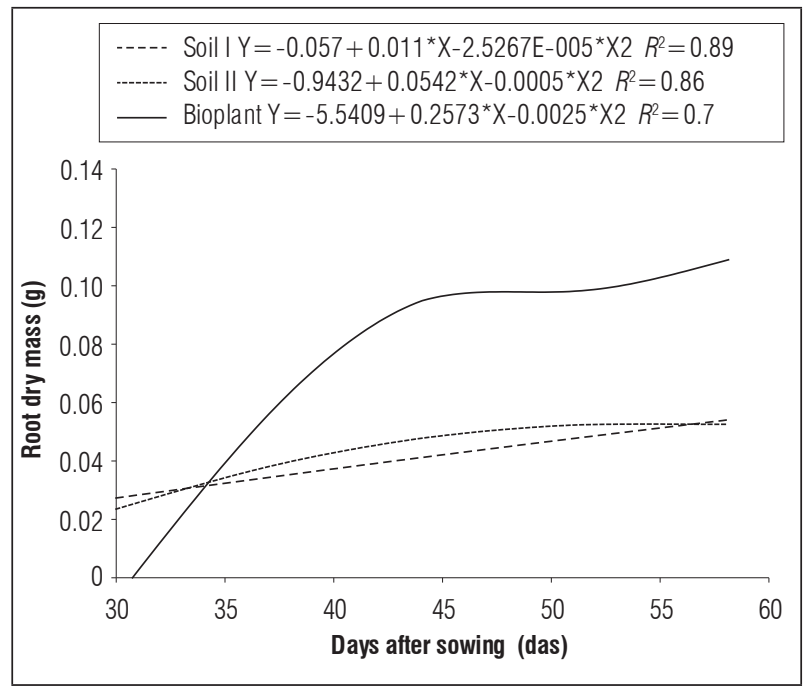

Figure 3. Adjusted data for root dry mass of 'FB 200' passion fruit plants in three substrates after sowing.

Comparing the results of Bioplant ${ }^{\circledR}$ with the other substrates, they also stood on dry matter accumulation during the evaluation period. However, this ended the root growth when there was exposure of the roots, if adjusting the quadratic model, in response to the variation of time. The values observed at 35,40 , 45, 50 and 55 das were respectively $0.0156,0.0419$, $0.1019,0.0707$, and $0.1355 \mathrm{~g}$ for FB 200.

These results are different to those found by Guerra et al. (2017) working with the same culture, in which the Bioplant ${ }^{\circledR}$ has not resulted in satisfactory conditions of yellow passion fruit seedlings growth. The same dissimilar results to those found in the present study were reported from studies that evaluated the influence of the substrate in the formation of forest seedlings, such as the initial development of seedlings of copaiba (Copaifera officinalis) under different levels of shading and substrates (Dutra et al., 2012); of Eugenia calycina (Borges et al., 2016) and with the germination and seed vigor of Crateavatapia in different substrates and temperatures (Alves et al., 2012), in all of these the use Bioplant ${ }^{\circledR}$ has not provided adequate root development.

According to Zucareli et al. (2014), the root system is directly connected to their dry weight, and lower dry weight results in less extensive root system, which implies in a smaller area to be explored in the soil. In yellow passion fruit seedlings, at $35 \mathrm{~d}$, the substrate Bioplant ${ }^{\circledR}$ resulted in a root dry weight of $0.0200 \mathrm{~g}$. In addition, at $40 \mathrm{~d}$, the values found were $0.0528 \mathrm{~g}$, followed by $0.1039,0.1528$ and $0.1994 \mathrm{~g}$ at 45,50 and 55 das, respectively, for yellow passion fruit plants in Bioplant ${ }^{\circledR}$ (Fig. 4). At 50 das, the second highest RDM was developed in Soil I. Already at $55 \mathrm{~d}$, the Soil I had lower values than the Soil II, which accumulated 0,0753 g of RDM. Miyake et al. (2017), working with substrates and nitrogen fertilization on the production of seedlings of yellow passion fruit in protected cultivation conditions, observed that the root dry mass in Bioplant ${ }^{\circledR}$ substrate presented the best response ( $4.0 \mathrm{~g} \mathrm{RDM})$ at $120 \mathrm{~d}$ after germination, being superior to the other substrates studied, a result similar to that found in the present study (Fig. 4).

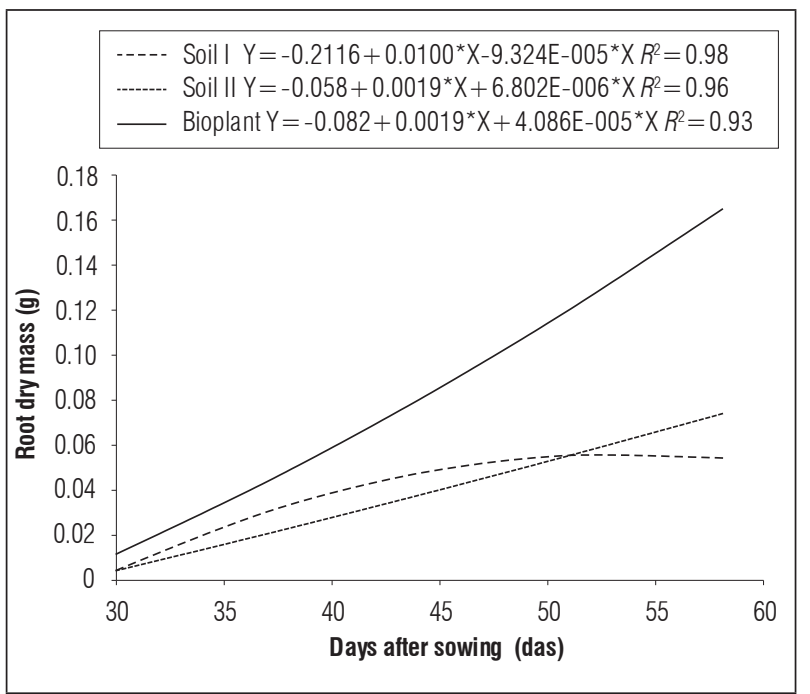

Figure 4. Adjusted data for root dry mass of yellow passion fruit (Passiflora edulis f. flavicarpa) plants in three substrates after sowing.

In relation to the root fresh weight of the yellow passion fruit, an exponential behavior was observed for the Soil I and quadratic for the Soil II and for Bioplant ${ }^{\circledR}$. At 30 das, the values found for Soil I, Soil II and Bioplant ${ }^{\circledR}$ were 0.2328, 0.2705, and 0,001 g, respectively (Fig. 5). 
The substrate Bioplant ${ }^{\circledR}$ has highest concentration of organic matter in its chemical composition and besides, it has adequate levels of calcium and phosphorus, which provides better absorption of water and nutrients by plants, reflecting on the best root

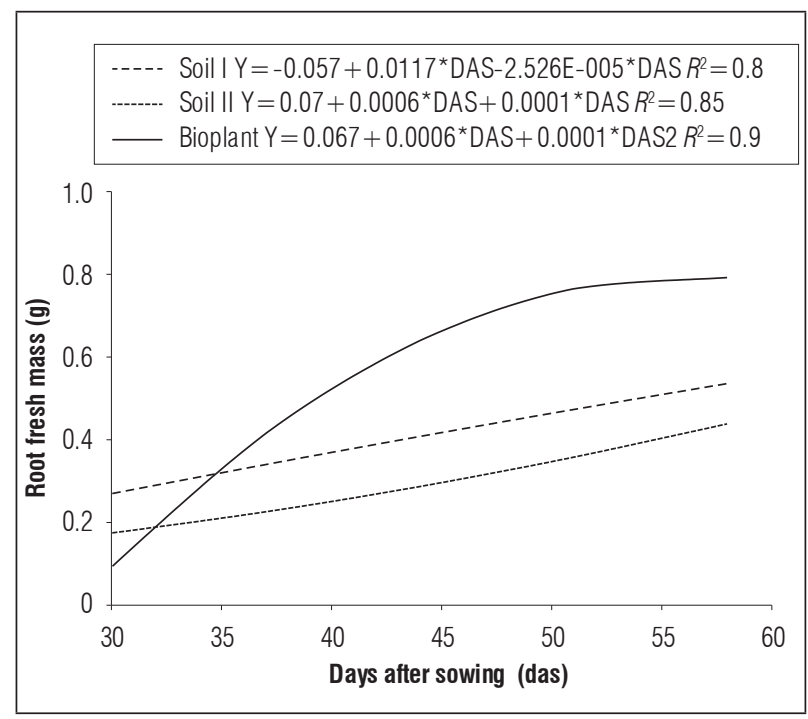

Figure 5. Adjusted data for root fresh mass of yellow passion fruit (Passiflora edulis f. flavicarpa) plants in three substrates after sowing. development of plants (Miyake et al., 2017). However, Lima et al. (2016) concluded that for the formation of passion fruit seedlings are not indicated substrates with high quantities of Bioplant ${ }^{\circledR}$ or sand, this is contrary to the results of our present study.

For the variable root morphology of the yellow passion fruit, as well as in the cultivar FB 200, we noted a difference in the formation of the root system (Fig. 6). The roots, developed in the substrate Bioplant ${ }^{\circledR}$, proved to be more ramified, presented greater size, but with a lower thickness. Roots from the Soil I were less widespread, but with a greater thickness, in relation to the others, and in this case, were almost similar to the size of those grown in the Bioplant ${ }^{\circledR}$ substrate. In the Soil II, the ramifications were longer and showed to be thicker, more consistent than in the Bioplant ${ }^{\circledast}$, but lower than in the Soil I.

According to Smiderle and Minami (2001), for the production of seedlings of fruit plants a good substrate must provide adequate water retention which allows a good germination and must maintain sufficient quantities of porous spaces that facilitates the delivery of oxygen, which is indispensable in the process of germination and root development, especially when the substrate is saturated (in excess of water).

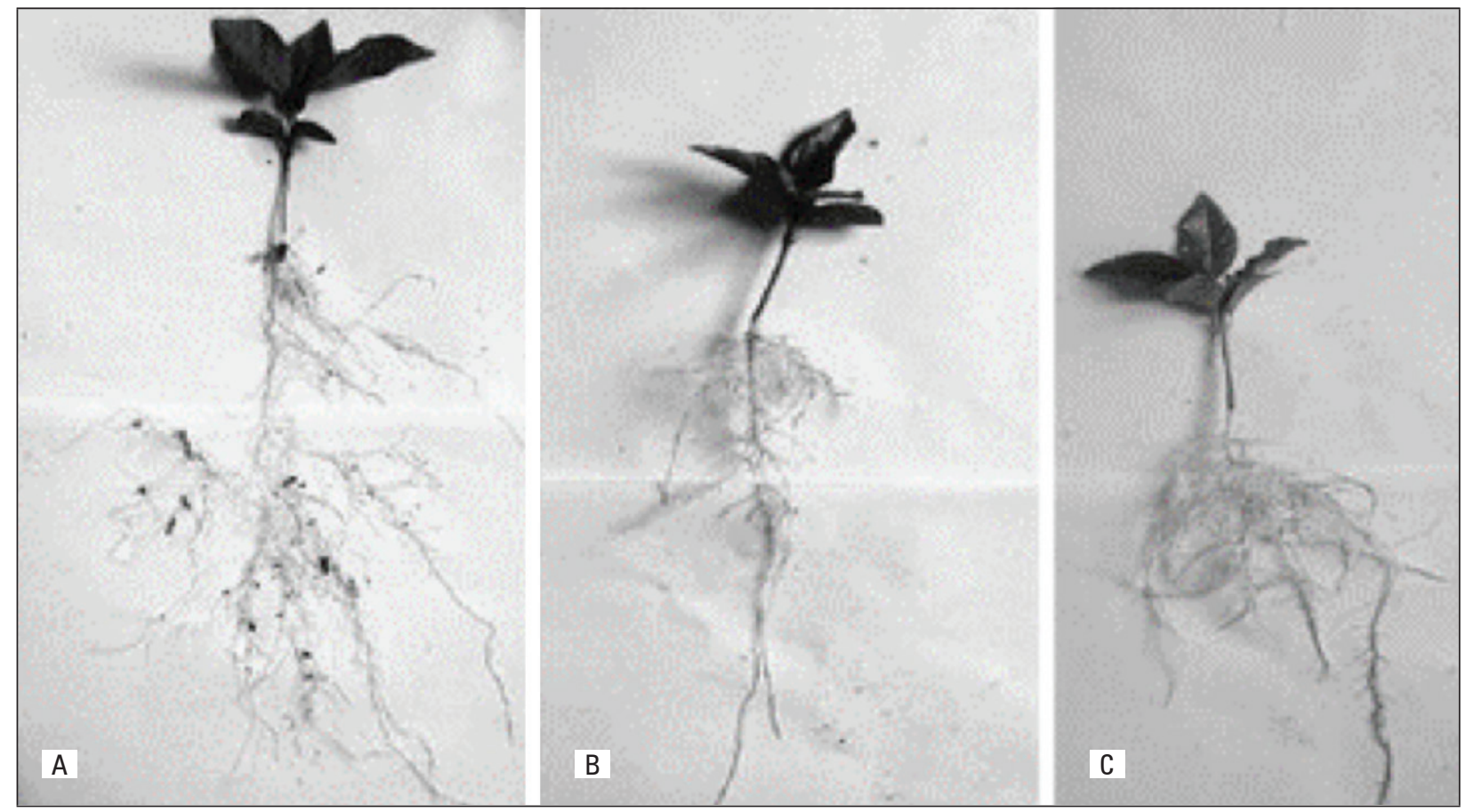

Figure 6. The root morphology of yellow passion fruit (Passiflora edulis f. flavicarpa) plants, $30 \mathrm{~d}$ after sowing in three types of substrate. A. Soil I; B. Soil II; C. Bioplant ${ }^{\circledR}$. 


\section{CONCLUSIONS}

The substrate promoted the initial development of yellow passion fruit and of cultivar FB 200 plants, with the best seedlings growth in the substrate Bioplant ${ }^{\circledast}$ showing a greater development of fresh and dry matter of roots.

Conflict of interests: the manuscript was prepared and reviewed with the participation of the authors, who declare that there exists no conflict of interest that puts in risk the validity of the presented results.

\section{BIBLIOGRAPHIC REFERENCES}

Almeida, M.O., M.C.M. Cruz, G.D.M. Castro, and M.C.P. Fagundes. 2014. Crescimento e absorção de nutrientes por mudas de maracujazeiro-amarelo em substratos orgânico e comercial e adubação nitrogenada. Rev. Bras. Ciênc. Agrar. 9(2), 180-185.

Alves, E.U., S.S.S. Moura, M.F. Moura, R.S. Guedes, and F.A. Estrela. 2012. Germinação e vigor de sementes de Crateavatapia L. em diferentes substratos e temperaturas. Rev. Bras. Frutic. 34(4), 1208-1215. Doi: 10.1590/S0100-29452012000400030

Borges, K., D. Santana, S. Lopes, and V. Pereira. 2016. Coloração do fruto e substrato na emergência e no crescimento de plantas de Eugenia calycinas Cambess. Floresta Ambient. 23(4), 544-554. Doi: 10.1590/2179-8087.144215

Cardoso, M.R.D., F.F.N. Marcuzzo, and J.R. Barros. 2014. Classificação climática de Köppen-Geiger para o Estado de Goiás e o Distrito Federal. Acta Geográfica 8(16), 40-55. Doi: 10.5654/acta.v8i16.1384

Dutra, T.R., P.H. Grazziotti, R.C. Santana, and M.D. Massad. 2012. Desenvolvimento inicial de mudas de copaíba sob diferentes níveis de sombreamento e substratos. Rev. Ciênc. Agron. 43(2), 321-329. Doi: 10.1590/S1806-66902012000200015

Ferreira, M.G.R., R.B. Rocha, E.P. Gonçalves, E.U. Alves, and G.D. Ribeiro. 2009. Influência do substrato no crescimento de mudas de cupuaçu (Theobroma grandiflorum Schum.). Acta Sci. Agron. 31(4), 677-681.

Gomes, F.P. 2000. Curso de estatística experimental. $14^{\text {th }}$ ed. ESALO/USP, Piracicaba-SP, Brazil.

Guerra, M.S., M.S. Barbosa, E. Costa, G. Haralampidou, and C. Vieira. 2017. Recipiente biodegradável e substratos para mudas de maracujazeiro, Rev. Agric. Neotrop. 4(3), 50-54.

Lenhard, N.R., V.B. de Paiva Neto, S.P.Q. Scalon, and A.A. Alvarenga. 2013. Crescimento de mudas de pau-ferro sob diferentes níveis de sombreamento.
Pesq. Agro. Trop. 43(2) 178-186. Doi: 10.1590/ S1983-40632013000200012

Leonel, S. and C.J. Pedroso. 2005. Produção de mudas de maracujazeiro doce com o uso de biorregulador. Rev. Bras. Frutic. 27(1), 107-109. Doi: 10.1590/ S0100-29452005000100029

Lima, I.M.O., J.S. Silva Júnior, E. Costa, E.D. Cardoso, F.F.S. Binotti, and M.H.A. Jorge. 2016. Diferentes substratos e ambientes protegidos para o crescimento de mudas de maracujazeiro amarelo doce. Rev. Agric. Neotrop. 3(4), 39-47.

Meletti, L.M.M. 2011. Avanços na cultura do maracujá no Brasil. Rev. Bras. Frutic. 33(1), 83-90. Doi: 10.1590/ S0100-29452011000500012

Miyake, R.T.M., J.E. Creste, N. Narita, and W.E.X. Guerra. 2017. Substrato e adubação nitrogenada na produção de mudas de maracujazeiro amarelo em condições protegidas. Colloq. Agrar. 13(1), 57-65. Doi: 10.5747/ ca.2017.v13.n1.a149

Nakagawa, J. 1999. Testes de vigor baseados na avaliação dasplântulas. pp. 49-86. In: Vieira, R.D. and N.M. Carvalho (eds.). Testes de vigor em sementes. FUNEP, Jaboticabal-SP, Brazil.

Negreiros, J., V.S. Álvares, L.R. Braga, and C.H. Bruckner. 2004. Diferentes substratos na formação de mudas de maracujazeiro-amarelo. Ver. Ceres, 51(294), 243-249.

Roncatto, G., G.C. Nogueira Filho, C. Ruggiero, J.C. Oliveira, and A.B.G. Martins. 2008. Enraizamento de estacas herbáceas de diferentes espécies de maracujazeiro. Rev. Bras. Frutic. 30(4), 1094-1099. Doi: 10.1590/ S0100-29452008000400041

Silva, W.L., A.S. Brito, C.F.B. Brito, N.L.S. Mesquita, and Y.C.P. Silva. 2016. Desenvolvimento de maracujazeiro em recipientes e substratos a base de resíduo de vermiculita. Agrotec. 7(1), 53-60. Doi: 10.12971/2179-5959/ agrotecnologia.v7n2 p53-60

Smiderle, O.S. and K. Minami. 2001. Emergência e vigor de plântulas de goiabeira em diferentes substratos. Rev. Cienc. Rur. 6(1), 38-45.

Statistical Analysis System. 2002. SAS Institute, Cary, NC.

Zaccheo, P.V.C., R.S. Aguiar, N.M.C. Stenzel, and C.S.V.J. Nevez. 2013. Tamanho de recipientes e tempo de formação de mudas no desenvolvimento e produção de maracujazeiro-amarelo. Rev. Bras. Frutic. 35(2), 603607. Doi: 10.1590/S0100-29452013000200032

Zucareli, V., O.E. Orika, C.S.F. Boaro, and W.P. Brambilla. 2014. Desenvolvimento inicial de maracujazeiros (Passiflora edulis f. flavicarpa, $P$. edulis f. edulis e $P$. alata) enxertados sobre Passiflora cincinnata. Ciên. Agrar. 35(5), $2325-2340$. 